\title{
Performance-Based Pay as a Motivational Tool for Achieving Organisational Performance: An Exploratory Case Study
}

\author{
Francis Boachie-Mensah (Corresponding author) \\ School of Business, University of Cape Coast \\ Cape Coast, Ghana \\ Tel: 233-332-137-870_E-mail: fbmens2002@yahoo.co.uk
}

\author{
Ophelia Delali Dogbe \\ Mount Zion School, Accra, Ghana \\ Tel: 233-242-965-648Ｅ-mail: eloloid@yahoo.com
}

Received: June 3, 2011

Accepted: August 5, 2011 Published: December 1, 2011

doi:10.5539/ijbm.v6n12p270

URL: http://dx.doi.org/10.5539/ijbm.v6n12p270

\begin{abstract}
The issue of employees' performance in furtherance of organisational objectives has occupied management attention for long. Differences in levels of performance have been attributed to differences in skills and abilities on the one hand, and to different theories of money on the other. This study examined the issue of performance-based pay as a motivational tool for achieving organisational performance, using the situation in a manufacturing company in Ghana as a case study. The main objective of the study was to assess the impact of performance-related pay on the motivation of employees and, subsequently, on the achievement of organisational goals. In all, one hundred and fifty respondents took part in the survey. The sample comprised 20 managerial staff and 60 non-managerial staff. The main research instrument was the questionnaire. A two-way ANOVA table was used to test the main hypotheses. The result of the study revealed that the effect of performance-based pay on employee performance is minimal; and the motivational effect of merit pay is often blunted by biased performance appraisal. The main limitation of the study is that it could not cover all manufacturing companies within the target population, due to time and financial constraints. In this respect, the interpretation of the results of the study should not be over-generalised.
\end{abstract}

Keywords: Compensation, Motivation, Rewards, Performance pay, Incentives

\section{Introduction}

Linking pay to performance is something employers increasingly seek to achieve. Jobs with performance related pay (PRP) attract workers of higher ability and induce workers to provide greater effort (Booth and Frank (1999). Much of the academic and policy literature on PRP focuses on its role as an incentive system (Marsden, 2004). In the public policy debate, it has been common to associate the introduction of PRP with the aim of improving incentives and motivation among public employees (Brown and Heywood, 2002). In Africa (Ghana inclusive) in particular, employees have for a long time been awarded financially on the basis of their entry qualifications and the perceived value of their job analysis and evaluation. For example, Fosh (1990), in her studies on attitudes to income inequalities in East Africa, found that differences in paper qualifications were the most cited reason for pay differentials. In addition, the design and operation of payment systems have been based upon custom and practice, as well as collective bargaining and characteristics of the labour market.

In recent years, there has been a discernable trend, particularly in the private sector, towards the linkage of rewards to employee performance in an attempt to enhance the achievement of organisational objectives (Mullins, 2005). Compensation is thus tied to performance. In many developed economies there has been a resurgence of interest in PRP, encouraged by governments (Perry, Engbers and Jun, 2009; Booth and Frank, 1999). This is consistent with the new view of organisations as a network of contracts linking incentives to performance (Dun-Icavy and Hood, 1994). As Milkovich and Newman (1996) observe, compensation is viewed from different perspectives by society, employees and managers. Society considers compensation as a measure of equity or justice, hence the slogan, 'equal work for equal pay'. This reflects the public outcry against 
discrimination of any kind in the distribution of rewards. Employees consider compensation as a return for services rendered. They see it as a reflection of their personal worth in terms of skills and abilities, as well as the education and training they have acquired. Managers, however, view compensation from two perspectives: as a major expense and as a possible influence on employee attitudes and behaviours through compensation-based motivational strategies. This potential to influence employees' work attitudes and behaviour, and, subsequently, the productivity and effectiveness of the organisation, is another reason why many people believe that pay decisions can become a source of competitive advantage (Milkovich, 1998; 16).

Total compensation may be divided into two major groups: intrinsic rewards and extrinsic rewards. Indirect rewards comprise protection programmes, pay for time not worked, like leave, absence due to illness, and employee services and perquisites. Direct rewards comprise the basic wage, including cost of living adjustments and performance-based pay. Paying for performance is the process of providing a financial reward to an individual, which is linked directly to individual, group and organisational performance (Armstrong, 2005). As Armstrong observes, there is a trend towards PRP in manufacturing firms.

Managers and other professionals around the world have expressed concern over the impact of fixed incremental systems on organisational goals. This is especially so where increments are awarded to employees as a matter of prerogative and unrelated to the assessment of performance. In many instances, employees are granted automatic promotion, with its financial implications, as it goes more with time bar or years of service. Incremental true-based systems might be of some value in encouraging a high degree of commitment, which may result in a high level of employee retention. But they are of little value in the current competitive business environment, which requires the use of appropriate performance-based strategies to achieve competitive advantage (Armstrong, 2005). Motivating employees to greater performance and productivity is considered one way to achieve such advantages. Incremental systems are explicitly associated with many people with unmotivated performance. The drive against incremental systems has taken place because management does not see why they should pay people more for being there (Armstrong, 2005; 100). Lupton and Bowey (1996) argue that compensation structure based on prerogative rewards may result in complacency and unproductive sense of security on the part of employees.

There have been numerous research studies on PRP in the human resource management literature, but very little research on the subject has included samples from non-Western societies (Baruch, Wheeler and Zhao, 2004). It is against this backdrop that this study seeks to focus on a sector of the Ghanaian situation. The main objective of the study is to assess the impact of PRP on the motivation of employees and, subsequently, on the achievement of organisational goals. The study seeks to evaluate the performance-based pay (PBP) system introduced in a manufacturing company in Ghana. The basic questions addressed are: Is the claim that PBP is superior to time-based pay as far as the attainment of corporate goals is concerned valid? Is the linkage with performance appraisal crucial and fair? It is expected that the results of this study will contribute to existing knowledge on the impact of PBP. It is also expected that the results will stimulate further interest in the subject which will serve as a basis for further research. Furthermore, the information generated would help policy makers to consider the feasibility of PBP as a yardstick in the public and private sector.

\section{Literature Review}

\subsection{Concept of Motivation and Performance Pay}

Motivating employees can be a manager's biggest challenge. Employee motivation is a key to the overall effectiveness of an organisation. Jones and George (2007) define motivation as psychological forces that determine the direction of a person's behaviour in an organisation, a person's level of effort and a person's level of persistence. The authors consider direction of behaviour, efforts and persistence as key components towards motivation. The behaviour that a person chooses is direction of behaviour. Effort measures how hard an employee works. Persistence occurs when an employee continues in the face of difficulties, instead of giving up.

The various theories of motivation altogether provide a firm theoretical basis for the study of the use of extrinsic rewards for motivating employees to higher levels of performance for the attainment of corporate goals (Schuler, 1998). As Perry, Engbers and Jun (2009) posit, support for PBP is theoretically grounded in expectancy theory (Pearce and Perry 1983) and reinforcement theory (Perry, Mesch, and Paarlberg, 2006). Expectancy theory is predicated on a belief that individuals will exert effort if they expect it will result in an outcome that they value (Van Eerde and Thierry, 1996). In the case of PBP, employees will work harder if they value monetary rewards and believe that those awards will result from their increased efforts. Reinforcement theory posits a direct relationship between a desired target behaviour (e.g., performance) and its consequences (e.g., pay). It suggests that pay can be used to create consequences for desired behaviours, such as high performance that will reinforce the behaviours (Perry, Mesch, and Paarlberg 2006).

The straightforwardness of this causal theory, however, is shown to be untrue by the number of important variables and the complexity of the postulated relationships identified in prior research (Perry, Engbers and Jun, 2009). In 
general, a variety of antecedent employee and organisational characteristics and environmental conditions, together with pay system design, affect critical intermediate variables, among them are job characteristics, job affect, and perceived pay system. These variables, in turn, influence affective and performance outcomes (Perry, Engbers and Jun, (2009).

There are several implications of the theories of motivation for management: Employee motivation is influenced by absolute as well as relative rewards. Inequity in the administration of compensation (due to unfair performance measurement) may affect the objectives of the company, as employees will learn to "play the game" in order to receive increased reward at the expense of contribution. And unless the total compensation package is perceived as internally equitable and externally competitive, good employees are likely to leave (Schuler, 1998).

The foregoing discussion highlights the importance of PBP for motivation on the job. It is the kind of compensation that is relevant in a study of the link between motivation and performance. It is the role of pay in motivating employees on the job that is the focus of this study, and not the impact of money on decisions to take up or to leave employment.

\subsection{Performance-based Pay}

Performance-based pay (PBP) is a compensation scheme that links employee performance with pay. It can be defined as a system of remuneration in which an individual's increase in salary is solely or mainly dependent on his/her appraisal or merit rating (Swabe, 1989). Armstrong (2005) defines it more comprehensively as the process of providing a financial reward to an individual which is linked directly to individual, group or organisational performance. But Schuler (1998) maintains that PBP is not limited to financial rewards, and that non-financial rewards, such as recognition, can also constitute pay for performance. The basic reasons for PBP are performance enhancement for competitive advantage and equity (MIlkovich and Newman, 1996). In this regard, Beardwell and Holden (1995) identify several specific reasons for which managers may introduce PBP. These include: help in recruitment and selection; facilitate change in organisational culture; weaken trade union power; increased role of the line manager; greater financial control and value for money; ability to reward and recognise performance; and encouragement to flexibility.

PBP can be divided into two main categories: merit pay and incentive pay. Schuler submits that merit pay relates compensation to management's assessment of the individual employee's performance; the increment earned (PBP) and the total becomes the employee's new basic pay. Incentive pay, on the other hand, relates compensation more to performance criteria, such as return on investment, volume of goods produced or sold, earning or share. While essentially one type of merit pay exists, there are a wide variety of incentive pay plans. Beardwell and Holden (1995) have broadly categorised incentive pay systems into three: individual bonus schemes; collective bonus schemes; and collective bonus schemes based on profit generated. The focus in this study is on merit pay, the effect of which is reviewed next.

\subsection{Effects of Merit Pay}

One of the first reviews of the effects of merit pay reforms was Perry's (1986) assessment of contingent pay for public managers. The scope of his review was limited to research on individual contingent pay systems that added performance increments to base pay. In his review, Perry could not identify any study that found positive effects. Although the evidence was limited, he concluded that merit pay in the public sector was plagued by invalid contracts, information asymmetries where the supervisor lacked accurate information about subordinate performance, and diminished capacity to coordinate interdependence (Perry et al., 2009).

As in the U.S, a National Research Council (NRC) panel reviewed both public and private sector research on pay for performance (Milkovich and Wigdor 1991). The panel's summary of findings concluded that "empirical research indicates that individual incentive plans can motivate employees and improve individual performance" (Milkovich and Wigdor, 1991; 153). The panel qualified this conclusion, however, by observing that individual incentive schemes are most likely to succeed for simple, structured jobs and in contexts in which trust is high and fair performance goals can be set. The implied connection between the panel's general conclusions and the organisational setting is that conditions for success may be difficult to realize in certain organisations.

Ingraham's (1991), and Kellough and Lu's (1993) work adds to the review of pay-for-performance research. Ingraham assessed pay for performance using secondary sources on federal programmes. Her primary focus was on the diffusion of PBP as a policy innovation and the reasons behind it. However, Ingraham also examined prospects for the success of pay for performance in governmental organisations. And she concluded that institutional conditions, such as laws and economic constraints, were not conducive to success in the public sector. Ingraham's conclusion about likely success of PBP is pessimistic, but her inference is qualified by circumstances (e.g., laws, procedures, funding) and not based on fundamental flaws in the approach (Perry et al., 2009). 
Kellough and Lu's (1993) work on reviewing empirical studies of merit pay sheds some more light on the topic. The studies covered, among others, state and local managers; school administrators; and nonsupervisory local government employees. Much like their forerunners', Kellough and Lu's conclusion was, "Generally, merit pay systems have had little positive impact on employee motivation and organisation performance" $(1993,48)$. They refer to one application as producing positive effects, but note that the impact of PRP was negatively affected by other changes implemented concurrently and higher pay overall. Among the specific reasons that they gave for merit pay not being more successful are difficulties with performance evaluation such as rater leniency and lack of resources to fund the systems at appropriate levels. They also raised similar questions as their forerunners about the environment precluding managerial discretion to link pay to performance and the validity of the motivational assumptions underlying the systems.

Perry, Mesch, and Paarlberg (2006) undertook a review of pay-for-performance research which was part of a study on motivation in the public sector. The study concluded that individual financial incentives are ineffective in traditional public sector settings and joined prior reviews of pay-for-performance systems in concluding that the effectiveness of financial incentives is dependent on organisational conditions.

Campbell and Campbell (1998) discuss merit pay and highlight three areas of importance: as a tool for achieving competitive advantage; as a reflection of the norm of distributive justice and as a practice in line with employee motivational theories (such as expectancy theory). The authors lament that in spite of the logical appeal of merit pay, it often results in outcomes precisely the opposite of the desired ones. In their paper they examine the problems associated with merit pay as well as important attribution errors that attenuate the effectiveness of merit pay and finally propose a group-based alternative. The five common problems they identify in connection with PBP relate to: measurement difficulties; feedback and acceptance (of assessment results by staff); limited desirability of merit reward; system noise (factors which obscure the effort-reward linkage), such as long time lapse between performance and reward, and conflicting use of financial and non-financial rewards. Finally, it addresses the issue of intended consequences, notably task in flexibility and reduction of intrinsic motivation. After examining the traditional solutions usually advanced for these problems, the authors conclude that they are inadequate and leave a basic problem unresolved, namely the problem of attribution.

\subsection{Employee Perceptions on Performance-based Pay}

In furtherance to assessing whether PBP affects individual and organisational performance, researchers also have considered its effects on several intermediate outcomes, particularly employee perceptions (Egger-Peitler, Hammerschmid, and Meyer, 2007; Heneman and Young, 1991. Researchers have focused on perceptions integral to the success of pay programmes from a motivational perspective and at attitudes towards programme implementation. In regard to employee perceptions about variables, such as expectancy, instrumentality, and valence (drawn from expectancy theory), researchers have found mixed results. In studies in which goals were clear, compensation was adequate, and a significant amount of support for merit pay plans existed, PBP resulted in positive outcomes (Perry et al., 2009). In many cases, however, the underlying foundation of expectancy theory failed to materialize. Some researchers found that respondents perceived little relationship between performance and compensation (Daley, 1987), that few believed higher pay would materialize (Pearce, Stevenson, and Perry, 1985), and that financial incentives were too small to be valued (Heinrich, 2007). Other researchers found that a lack of financial motivation existed in pay-for-performance systems (Dowling and Richardson, 1997) and that distaste existed among employees for the divisive side effects among employees that merit pay could produce (Marsden, 2004).

\subsection{Contextual Factors Affecting Performance-based Pay}

Several contextual factors appear to be associated with the success of PBP (Perry et al., 2009). These include high levels of trust, adequate rewards, effective performance appraisals, close geographic proximity (Brudney and Condrey, 1993; Condrey and Brudney, 1992), and degree of professionalism (Andersen, 2007). Among others, research in the regulatory and financial sectors found that PBP is generally perceived as divisive (Bertelli, 2006; Marsden, 2004; Marsden and Richardson, 1994). Andersen and Pallesen's (2008) studies on PBP within the education sector found that, except in the most unique situations, the impact on employee attitudes and intrinsic motivation was negative.

A factor that appears to affect the effectiveness of public PBP is whether it is applied to managers or nonmanagers. Although a significant majority of the studies in this field of research involved managers, research on nonmanagers accounts for a disproportionate share of positive performance results. This is consistent with Milkovich and Wigdor's (1991) study, which found, among other things, that PBP systems are best suited for positions in which job responsibilities are fairly concrete and measurable. Differences in effectiveness, however, should not be overstated (Perry et al., 2009). This evidence contradicts existing sentiment that PBP plans will be more effective at higher organisational levels (Risher and Fay, 2007). 
Nevertheless, employees generally perceive the implementation of PBP as unfair (Kellough and Selden, 1997). The reasons behind the perceptions are varied and sometimes difficult to identify, but include low levels of organisational trust (Condrey and Brudney, 1992), lack of transparency in the systems for employees (Egger-Peitler, Hammerschmid and Meyer, 2007), lack of trust in performance-rating systems (Kellough and Selden, 1997), and lack of leadership credibility (Gabris and Ihrke, 2000).

Finally, regardless of organisational level, improvements in performance measurement and management that are independent of pay incentives may account for performance increases by improving goal setting. The beneficial aspect of PBP that emerges from the research appears not to be the product of the pay scheme but rather the development of performance standards. The use of performance standards has repeatedly been shown to be the most beneficial aspect of performance pay plans (Fletcher and Williams, 1996). In one instance, the introduction of pay into the performance measurement process resulted in a negative impact on performance (Hatry, Greiner and Gollub, 1981).

Although research has identified occasional performance pay successes, the programmes typically have fallen short of intermediate and long-term expectations. The reasons for the persistent failure of PBP are more likely its incompatibility with public institutional rules, proponents' inability or unwillingness to adapt it to these values, and its incompatibility with more powerful motivations that lead many people to pursue public service in the first place (Perry et al., 2009).

\subsection{Implementation Constraints}

Implementation breakdowns account for some failures of PBP but are not the only reasons for failure. Multiple studies have found that employees support the idea of pay for performance in the abstract but believe that its implementation in their organisation is plagued by problems (Egger-Peitler, Hammerschmid and Meyer, 2007; Kessler and Purcell, 1992; Marsden and Richardson, 1994). In addition, one of the most consistent findings about PBP initiatives is that they are poorly implemented, with the absence of good performance management practices a critical flaw (Perry et al's, 2009). Campbell and Campbell (1998) indicate that the limitations of merit pay are basically due to the differential attribution of performance. Attribution theorists have documented that an actor (employee) and observer (rator) do not perceive performance causality in the same way (Campbell and Campbell, 1998). The supervisor typically attributes low performance to factors internal to the employee, whereas the employee attributes it to external factors. Thus, even if the two agree on the fact of low performance, they are likely to disagree about its causes. The authors finally propose a work unit based approach as more likely to achieve the goals of merit pay because it can reduce significantly the problems of measurement and equity. The measurement of group performance can be based on more objective criteria, while the problems of subjectivity and inter-dependency can be reduced. The objective performance indicators provide feedback without the interpersonal evaluation component in traditional appraisal. The preference of the authors for group-based incentive systems is clear.

Milkovich (1996) reviewed twenty-six scientific studies in search of answers to the following questions: Does PBP really work? And which approach makes the most sense? Milkovich analysed his findings from the individual and group-based perspectives. He observed that merit pay is the only PBP system to focus on the long-term, with a compounding effect on stock and an annuity effect on employees' earnings. On the firm level of performance, he concluded that the use of incentive pay for managerial employees resulted in improved performance. However, in a series of experiment, Deutsch (1995) found no conclusive evidence to support the claim that individuals work more productively when their individual earnings are tied to their performance. The participants seemed more motivated by their own desire to excel than by the prospect of increased remuneration in winner-takes-all or equity situations. He observed, though, that compared to competitive, individual payment systems, co-operative systems had more favourable effects on performance, friendly feelings and group morale. Schuler (1998) suggests that incentive pay plans generally appear to have substantially more motivational value than merit pay plans. But merit pay plans remain much more frequent because they tend to be easier to set up and administer. This agrees with the views of MIlkovich (1996) and Campbell and Campbell (1998) who maintain that merit plans, on occasions, produce effects contrary to what is expected.

The major problem encountered in the implementation of merit pay is related to its link to performance appraisal. The linkage between PRP systems and individual appraisals can be analyzed along three dimensions: setting performance objectives or criteria; the assessment of performance and developing the link between pay and performance (Kessler and Purcell, 1992). Beardwell and Holden (1995) make a distinction between input-based and output-based criteria. They explain input-based criteria as relating to the personal characteristics, traits, competencies and skills which an employee brings to a company or job. And output based criteria are concerned with individual performance. The authors emphasise that irrespective of the perspective taken, the setting of performance criteria has always been a challenge for managers. The way out of this dilemma is to involve employees as much as possible in the setting of objectives (Beardwell and Holden, 1995). However, regardless 
of the effort to gain the consent of staff, there exist difficulties of establishing realistic performance criteria for certain occupations, such as teaching and the military. To help overcome such challenges, Campbell and Campbell (1998), among others, suggest that firms move away from highly subjective judgments to more specific and objective measurements. Organisations should also invest in the training of appraisers, to avoid common errors that occur in performance measurement. The second phase of the appraisal process is the actual measurement of performance, which is liable to contamination by a number of common errors. Some common errors in performance appraisal are known as 'constant errors' - those that are due to some systematic bias in the assessor (Blunt and Papoola, 1990).

Another critical factor to effectiveness of merit pay is the pay differential, that is, the size of the annual increment. Where employees consider the pay differential as of little consequence, it may not be motivating enough to put in the necessary effort for the achievement of organisational objectives. Wallace and Fay (1998) emphasise that an effective merit pay system requires the budgeting of sufficient funds for meaningful differentials. And they suggest that large performance differences should be rewarded with suitably large differentials. In this regard, Lawler (1981) suggests a minimum of 3\% pay increase for an individual to notice a difference. He contends that the differential between poor and outstanding performance is typically too small. Henderson (1998), on the other hand, suggests $4 \%$ as the minimum pay differential between high and low performers. All these point to the fact that PBP (merit pay) tends to be inflationary, and payments may overtake actual production.

Apart from the universal problems associated with performance appraisal described above, Blunt and Popoola (1998) draw attention to an aspect of organisational life in Africa which is pervasive and affects the functioning of the organisation: the problem of corruption. They distinguish between individual corruption and systematic corruption. Individual corruption occurs when organisational members contravene actual norms of honest administration and accountability, which are observed by the organisation as a whole. It can be kept within bearable limits through standard organisational control procedures. Systematic corruption, on the other hand, has been defined as 'deviant conduct which is so institutionalized that no individual can be personally faulted organisationally for participation (Blunt and Popoola 1998). It affects the functioning of the whole system (Caiden and Caiden, 1997; 341). The issue of systematic corruption has been identified in a study by Price (1995) on the Ghanaian Civil Service. Price notes that the criteria for upward mobility within the Ghanaian Civil Service mirror exactly those of Western countries. They emphasise on efficiency, qualification, seniority, experience and sense of responsibility. However, the actual criteria used were quite unrelated to performance.

\section{Methodology}

The research employed a case study design approach. Data was collected from 80 respondents, comprising 60 non-managerial and 20 managerial staff of the company. The case study approach was adopted in line with Neuman's (2007) suggestion that it should be used to investigate 'how' and 'why' questions, when the investigator has little control over events, and when focus of research is on contemporary phenomenon. In line with the case study design approach, questionnaires were used as the main data collection instrument. A probabilistic sampling method was applied. Due to the geographical location, number of employees in the organisation and ease of assessing respondents, the simple random sampling technique was preferred. Data collected from the 80 respondents was generalised for the population of employees from organisations in Ghana. The respondents were from the various departments in the company. There was a need for a departmental representation to enable a holistic assessment of the performance-based pay system and the challenges to be known for the purpose of generalisation. The population and sample of the various respondents are illustrated in Table 1.

\section{Insert Table 1 - here}

The researchers personally administered the questionnaire with the assistance of some staff members in the company. Respondents were given a period of two weeks to complete the questionnaires. In addition to the use of questionnaire, interviews were conducted with the Human Resources, Finance and Production Managers.

The data collected was edited, coded and processed, using he Statistical Package Science Solutions (SPSS). Descriptive statistics were used to analyse, describe and interpret the data. The Pearson Correlation was used to determine whether a relationship existed between the implementation of PBP programmes and organisational performance. The t-test of independence was used to determine or compare the strength of the relationship between two variables of the sample, that is, before and after the introduction of PBP. This was done in line with Saranthacos' (2007) suggestion that the t- test of independence should be used to test the strength of two variables as to which is more significantly associated. The level of significance chosen was $5 \%(0.05)$. The null hypothesis was accepted when the p-value was smaller than the significant level. The alternative hypothesis was rejected when the p-value was very small, hence more evidence in favour of the alternative. 


\section{Results and Discussion}

\subsection{Awareness of Standard of Performance}

In finding out whether employees were aware of the standard of performance, the researchers observed that $87.5 \%$ respondents were aware of their standards of performance in the organisation. Ten percent of them were not sure of their standards and the remaining $2.5 \%$ did not know their standards of performance in the company. The information is represented in Table 2. As to whether respondents were motivated by the linkage of pay to job performance, $81 \%$ of them answered yes, $13 \%$ were not sure and the remaining $6 \%$ answered no - they were not motivated as assessment was based on favouritism. The details of the response are illustrated on the pie chart in Figure 1.

\section{Insert Table 2 - here \\ Insert Figure 1 - here \\ 4.2 Assessment of Corporate Performance before and after Introduction of PBP}

A not-so-significant improvement in organisational performance since the introduction of PBP was observed. In order to assess the effect of PBP on corporate performance, the company's performance under PBP was compared with those before and after the introduction of PBP. Table 3 presents the ROCE for the years $1994-$ 2004. The year 1999 saw the introduction of PBP. With 1999 as base year, the five-year period before PBP was compared with the five-year period after PBP in terms of corporate performance (ROCE). The information in Table 3 is presented in the form of a line graph to enhance pictorial perception in Figure 2.

$$
\begin{aligned}
& \text { Insert Table } 3 \text { - here } \\
& \text { Insert Figure } 2 \text { - here }
\end{aligned}
$$

\subsection{Effects of PBP on Teamwork}

In response to respondents estimation as to whether PBP motivates or de-motivates teamwork, $56.7 \%$ of them responded yes to motivation, $25 \%$ were de-motivated and the remaining $18.7 \%$ were not sure as to whether it motivates or de-motivates. This is shown in Table 4.

\section{Insert Table 4 - here}

On the choice of PBP system, $15 \%$ of respondents opted for the individual system, $25 \%$ preferred the group-based scheme, while the remaining $60 \%$ preferred both the individual and the group-based systems of motivation. This is illustrated in Figure 3.

$$
\text { Insert Figure } 3 \text { - here }
$$

\subsection{Importance of Performance Assessment}

Of the 80 respondents favourably disposed towards PBP, the responses that were obtained are illustrated on the bar chart in Figure 4.

$$
\text { Insert Figure } 4 \text { - here }
$$

\subsection{Hypothesis Testing}

In hypothesis testing, if the P-value is less than the level of significance of $0.05 \%$, then the null hypothesis will have to be rejected. The alternative will be more acceptable if the P-value is very small. This alternative hypothesis is accepted because the P-value is very small (0.001), as compared to the significance level of $0.05 \%$.

\section{Hypothesis 1}

$\mathrm{H}_{0}$ : $\mathrm{PBP}$ is not positively correlated with higher employee and organisational performance.

$\mathrm{H}_{1}$ : $\mathrm{PBP}$ is positively correlated with higher employee and organisational performance.

\section{Insert Table 5 - here}

Table 5 shows that there is a negative correlation (-0.132) in the relationship between PBP and organisational performance at the company. Inclusively, there were no significances $[p=0.427, p=n . s]$ in organisational performance. In conclusion, $\mathrm{H}_{0}$ is accepted and $\mathrm{H}_{1}$ rejected. This implies that PBP is not positively correlated with higher employee and organisational performance.

\section{Hypothesis 2}

$\mathrm{H}_{\mathrm{o}}$ : There is no significant difference in the performance of the company before than after the introduction of PBP

$\mathrm{H}_{1}$ : There is a significant difference in the performance of the company before than after the introduction of PBP 
Insert 6 - here

To test for the difference between PBP before and after its introduction at Nestle Ghana Limited, a 95\% confidence level was considered. The result, as presented in Table 6, shows that there was a significant difference $[\mathrm{p}(148,2)=0.008, \mathrm{p}<0.05, \mathrm{p}=\mathrm{s}]$ in before $[\mathrm{M}=37.413, \mathrm{SD}=2.534]$ than after $[\mathrm{M}=32.753 \mathrm{SD}=1.021]$, on the perception that performance was better before PBP than after PBP. The hypothesis $\left(\mathrm{H}_{1}\right)$ that there is a significant difference in the performance of the company before than after the introduction of PBP was confirmed by the data.

\section{Discussion}

\subsection{Performance Pay in the Organisation}

Even though there are various forms of performance-related pay, the discussion focuses on merit pay as the specific form of the system in operation at the company. The extent of success in terms of the objectives for introducing merit pay, including fairness and motivation, will be measured against the empirical data obtained.

On the issue of merit pay and staff motivation, $81 \%$ of respondents were favourably disposed towards PBP. They indicated that they were happy with the system. Seventy percent of them indicated that the system was fair and motivating. This compares favourably with the $80 \%$ who felt personally motivated. The analysis suggests that the aims of the organisation for introducing PBP had been achieved to a large extent. In spite of the fact that 16\% of respondents did not feel motivated by the PBP system, not one employee opted for an alternative arrangement without it. There could be at least two reasons for this: either employees could not conceive of a better system, or that employees were dissatisfied with the 'modus operandi' of the system, rather than the actual scheme. In response to the suggestion of an alternative arrangement without PBP, $92 \%$ responded with a categorical no, while $8 \%$ were undecided. This seems to confirm the logical appeal of merit pay as a tool in support of a meritocratic philosophy of remuneration (Armstrong, 2004). In other words, individual contributions matter and should reflect in the pay of the individual. The dissatisfaction level of $30 \%$ of the respondents was quite high, which restricted the resultant effect of the scheme to $36 \%$. This still indicated a positive impact of PBP, which is expected to reflect in enhanced corporate performance. The empirical evidence, however, suggests the contrary.

On the issue of merit pay and corporate performance, the evidence (see Table 3 and Figure 2) suggests a marked difference in the return on capital employed (ROCE) between the periods 1994-1999 and 1999-2004. The introduction of PBP in 1999 coincided with a 4.4\% increase in ROCE from the previous year's. This raised the hope for a successful operation of PBP for higher productivity and competitive advantage. However, this increase was followed by a $14.4 \%$ decrease in 2000 and a further $24.4 \%$ fall from 2000 to 2004 . In effect, within two years of the introduction of the scheme, the ROCE had fallen by $56.4 \%$, that is, from $9.4 \%$ to $4.1 \%$. Furthermore, the average ROCE for period A (1994-1999) was 9.8\%, while the corresponding figure for period B (1999-2004) was $6.9 \%$ - a difference of $2.9 \%$. The hypothesis that there is a significant difference in the performance of the organisation before establishment of PBP than after was confirmed (see Table 6) [p $(148,2)=0.000, \mathrm{p}<0.05, \mathrm{p}=\mathrm{s}]$. This confirms what Schuler (1998) suggests, that incentive pay plans in general appear to have substantially more motivational value than merit pay plans. But merit pay plans remain much more frequent because they tend to be easier to set up and administer. This also agrees with the views of Milkovich (1996), and Campbell and Campbell (1998) who even maintain that merit pay plans, on occasions, produce effects contrary to what is expected. In this study, merit pay plans coincided with lower corporate performance.

As the literature suggests, the problem encountered in the administration of merit pay is linked to performance appraisal. The linkage between PRP schemes and individual appraisals should be analyzed along three dimensions: setting performance objectives or criteria, the assessment of performance and developing the link between pay and performance (Kessler and Purcell, 1992). It is significant to note that the first problem mentioned with respect to PBP in the company of study was the difficulty of establishing realistic and challenging targets for staff. The problem involved setting targets that were both challenging and realistic. Setting a low target would mean under-utilization of the capabilities of staff, whereas setting targets too high would potentially result in staff being penalized unnecessarily. This would eventually make the scheme counter-productive. The way out of this dilemma would be to involve employees in the setting of objectives (Beardwell and Holden, 1995). It would, thus, be important that the appraisal system be set up in an atmosphere of openness.

The second phase of the system involves the actual measurement of performance, which is liable to contamination by a number of common errors, like rator leniency and severity (Blunt and Papoola, 1990). Lenient supervisors tend to assess all or most employees favourably, while severe ones tend to assess employees unfavourably. This results in producing skewed distributions to the left and right sides of the normal curve (Blunt and Popoola, 1990). The specific situation at the company was the tendency by supervisors to overrate 
staff. One implication of this is that employees might be paid higher salaries than they deserved, and made no meaningful contribution towards the achievement of competitive advantage. It is significant to note that management reported a not-so-significant improvement in employee performance. That is, there was relatively a small difference in employee performance for the better. It is worth mentioning that the tendency to overrate employees has cultural undertones in the African setting (Ghana inclusive). It is the situation where people are generally unwilling to make negative assessments of others in the workplace, especially with respect to issues concerning remuneration (Blunt and Popoola, 1990). This is so because severe assessors would be accused of being the cause of low remuneration of staff in their divisions, while employees in other divisions enjoy a higher total remuneration because they have more lenient supervisors. This situation could result in inter-divisional rivalry and supervisor-employee conflicts (Margerison's, 1997).

Another inherent problem of a merit-pay plan is that of inter-related performances, where the tasks of two or more people are tied together. The problem here involves the ability to separate the unique contributions of the individuals concerned. Even if this were possible, some investigators (e.g., like Deming, 1996), have questioned whether the separation would be necessary. This is so because employees are not individually in control of their results, since their output is dependent on those of other employees. From the perspective of employees, the issue of actual measurement of performance is a major cause of dissatisfaction. It is significant to emphasise that the $36 \%$ of employees at the company who expressed antipathy towards PBP attributed their stance to dissatisfaction with the assessment of their work. They perceived favouritism in the system of assessment. The dissatisfaction of such a high proportion of the workforce would likely adversely affect total employee morale.

An equally critical factor to the effectiveness of a merit-pay plan is the pay differential (i.e., the size of the annual increment). Where employees consider the pay differential as of little consequence, it may not be motivating enough for them to put in the necessary effort for the achievement of organisational objectives. The evidence of the study indicated that the pay differential at the company was low. There should be sufficient funds for meaningful pay differential (Wallace and Fay, 1998). An effective merit pay system requires the budgeting of sufficient funds for meaningful differential. Large performance differences should be rewarded with suitably large differentials (Wallace and Fay, 1998). Merit pay tends to be inflationary, and payments may overtake actual production. Companies, therefore, resort to the use of low differential or altering the assessor's criteria, making them more stringent, thereby reducing the total amount expended on the system (Lawler, 1981 and Henderson, 1998). This, however, implies a limitation on the motivational effect of the system.

\subsection{The Problem of Attribution and Proposed Antidote}

As the literature suggests, even with a flawless performance appraisal system, individual defensiveness and the consequent supervisor-employee conflict cannot be eliminated completely because of the problem of attribution (e.g., Campbell and Campbell, 1998). To the extent that subjectivity is involved in the measurement of performance, attribution conflict will occur. Consequently, this will affect morale and productivity. Thus, attribution problems constrain the effectiveness of merit pay. The training of assessors can help minimize the attribution problem, by convincing the employee of the accuracy of the assessment. But the disagreements as to the cause of low performance are likely to persist. Campbell and Campbell (1998), in exploring the problems involved with individual performance appraisal, propose a group-based alternative as more likely to achieve the crucial goals of performance enhancement and transparent equity. It is significant to note at this point that only $15 \%$ of respondents in the study opted for individual schemes. Eighty-five percent of them opted against it $25 \%$ for a group-based system and $60 \%$ for a combination of individual and group-based systems. A group-based approach would bring more objectivity into performance assessment, reduce the incidence of personal victimisation and defensiveness, and encourage cohesion within the work unit (Campbell and Campbell, 1998). The need to establish measures to control individual contribution, however, would remain an outstanding issue.

\subsection{Mitigating Factors}

From the data, it is evident that the period of merit pay corresponded with a markedly lower ROCE (see Figure 2). However, the magnitude of the decrease was so great as to warrant the search for possible attenuating factors. Further probing revealed that during the period 1994-1996 the company embarked on self-renewal efforts by investing heavily in new plant and equipment. It also invested in the marketing sector through greater expenditure on advertising, sales promotion and marketing research. This was meant to counter the effect of stiffer competition resulting from the trade liberalization policies of the government. With the decrease in net profits, the ROCE was adversely affected. In effect, the company followed a long-term profitability strategy during the other period. With such a strategy, resources were committed to such long-term activities as research and development, training, acquisition of new plant and equipment.

Figures were not available on the level of investment, expenditure on wages and salaries, depreciation and 
marketing research. This made the actual effect of mitigating factors difficult to measure. It was difficult to determine whether the company would have recorded higher profits without self-renewal efforts. In the absence of such hard figures, the researchers had to resort to other qualitative data to help determine the trend of corporate performance during the period 1994-2004. Incidentally, there was some evidence to suggest that the company had been on a downward course in the years just before 1999. The following quote from the Managing Director's report to staff at the end of 2001 is quite revealing:

"In my memorandum to you at this time last year, I mentioned that we were at a watershed in our operation here in Ghana, with an opportunity to reverse the volume of decline and grow the company" (Nestle Newsletter: Jan-Dec., 2005, p 15).

Based on the said report, it was safe to infer that, due to the extra expenses caused by the company's strategic initiatives, there had been a decline in corporate performance in the years immediately following the introduction of the merit-pay plan in 1999. It was, therefore, established that the five-year period preceding the establishment of PBP was more profitable for the company than the five-year period after the system.

\subsection{Motivation and Corporate Performance}

From the analysis of the data, the evidence suggests a contradiction between the level of staff motivation and that of corporate performance. Even though the majority of employees indicated their satisfaction with PRP, this did not reflect positively on organisational output. The two possible reasons for this situation are: the low pay differentials in the system, which minimised the level of motivation, and the details of the methodology applied. Regarding the later, the stringent restrictions imposed by the management of the company to prevent direct contact with employees (to avoid time wastage) did not make it possible for face-to-face interviews with staff. The questionnaires were thus given to the management for distribution to staff. Hence, the psychological influence of management on staff who might have wished to give unfavourable responses could not be ignored. It was possible that the true level of motivation was much lower than what was indicated by staff. In this situation, the correlation between employee motivation and corporate performance would be more logical.

\section{Conclusion and Recommendations}

The study revealed that the use of PBP was fair and motivating, and there were no adverse effects of the system on teamwork. The reasons advanced for a teamwork alternative were that it drastically reduced inter-dependency of employees by measuring performance of a whole team. The result of the study revealed that the effect of PBP on employee performance was minimal as the motivational effect of merit pay had been blunted by biased performance appraisal. The study also showed that PBP system was underpinned by performance appraisal. But biased and negative assessments of employees' performance drastically affected the success of the system at the company. The results were not consistent with the hypotheses that PBP is positively correlated with higher employee and organisational performance. The independent $t$-test of results further established that there was a significant difference in corporate performance before PBP than after. Hence, the hypothesis that PBP has a positive relationship with corporate performance, which was measured by the ROCE, was not confirmed. It was found out that self-renewal efforts accounted for this state of affairs. Notable among them were problems of attribution, heavy investment in new plant and equipment, huge expenditure on vigorous promotional strategies and increase in staff strength in the marketing department.

On the strength of the findings of the study, the following conclusions can be drawn: PBP (merit pay) supports a meritocratic philosophy of compensation. That is, individual performance is important and should reflect in the individual's compensation package. It may not necessarily result in a higher level of productivity, but it can keep employees from being dissatisfied, if it is administered by trained assessors. The effect of merit pay on employee performance was minimal at the company. The motivational effect of merit pay may have been blunted by the various common errors associated with staff performance appraisal systems, which make the level of subjectivity rather significant. The existence of management-employee conflicts in merit-pay plans is due to the significant level of subjectivity involved in the basic component of performance appraisal. There will also be the psychological problem of attribution. The situation will persist, unless these problems are adequately addressed. Most employees are favourably disposed to the performance-reward linkage, provided the scheme is administered with objectivity and fairness. There is no evidence from the study to suggest that PBP is positively correlated with higher employee and corporate performance. This is because the ROCE before the introduction of PBP was greater than after the introduction of the system. Hence, it can be said that corporate performance at the company was better before than after the introduction of the system. The hypothesis that PBP is positively correlated to higher employee and corporate performance is, therefore, rejected pending information to the contrary.

Based on the conclusions drawn, the following recommendations are made: Organisations wishing to adopt a PBP system should have clear objectives for it. The objectives should be clearly spelt out and discussed with 
employees in an integrative and positive way. Attempts should be made through employee involvement to allay any fears, suspicion and mistrust that staff may have towards the system. Adequate preparations are necessary before introducing the system. The organisational culture, availability of qualified assessors, etc should be attended to for a successful operation of the scheme. Paying for performance should, as much as possible, be based on incentive schemes, rather than merit rating. Incentive systems which are based on relatively objective indices of performance leave little room for disagreements. They are, therefore, more likely to achieve their objectives.

Furthermore, in addition to the standards of performance, the rewards associated with different levels of performance should be determined beforehand. Incentive packages are potentially more motivating to employees. Thus, no matter the level of monetary motivation, staff may experience low morale and manifest such withdrawal behaviours as absenteeism, intention to turnover and actual turnover, if their dignity as human beings is not respected. Group-based schemes should be considered above individual ones. Such schemes have the potential of reducing individual victimisation and defensiveness. It enhances cohesion and co-operation. This will, in turn, affect corporate performance positively. Many organisations should be encouraged to adopt the use of merit-pay plans. Steps should be taken to ensure that the appraisal system involved is carried out in a professional manner. Funds should be committed to the training of assessors or managerial staff in order to reduce the errors inherent with the assessment of staff. Involvement of employees in their assessment can help reach an agreement faster. In this regard, the trend towards self-assessment should be encouraged.

The major weakness in this study is that it was limited in scope. This means that the findings cannot be over generalized. Future research should focus on case studies of other sectors and organisations in other locations, since this study was on only one company. A comparative study among organisations in the same sectors should be conducted in order to determine whether the use of PBP enhances employee and organisational performance. The dimensions found in this study should be regarded as preliminary. Although they appear to be stable and measurable, they are not necessarily exhaustive and should be viewed as a starting point for additional research.

\section{References}

Adams, J. S. (1965). Inequity in Social Exchanges. (2nd Ed.). New York: Academic Press. http://dx.doi.org/10.1016/S0065-2601(08)60108-2

Andersen, L. B., \& Pallesen, T. (2008). Not Just for the Money? How Financial Incentives Affect the Number of Publications at Danish Research Institutions. International Public Management Journal, 11 (1): 28 - 47. http://dx.doi.org/10.1080/10967490801887889

Andersen, L. B. (2007). Professional Norms, Public Service Motivation or/and Economic Incentives: What Motivates Public Employees? Paper presented at the Annual Conference of the European Group of Public Administration, Madrid, Spain, September $19-22$.

Armstrong, M. (2005). A Handbook of Human Resource Management Practice. (5th Ed.). Ohio: Kogan Page.

Baruch, Y, Wheeler, K \& Zhao, X. (2004). Performance-Related Pay in Chinese Professional Sports. International Journal of Human Resource Management, $15 \quad$ (1): 245-259. http://dx.doi.org/10.1080/0958519032000157447

Beardwell, I., \& Holden, L. (1995). Human Resource Management: A Contemporary Perspective. London: Pitman Publishing.

Benett, R. (1994). Organizational Behaviour, (2 ${ }^{\text {nd }}$ Ed.). New Jersey: Longman.

Bertelli, A. (2006). Motivation Crowding and the Federal Civil Servant: Evidence from the U.S. Internal Revenue Service. International Public Management Journal, 9 (1): 3 - 23. http://dx.doi.org/10.1080/10967490600625191

Blunt, P., \& Papoola, O. (1998). Management in Africa. Human Resource Management Journal, 33: 23 - 30.

Blunt, P., \& Popoola, O. (1990). Personnel Management in Africa. Human Resource Management Journal, 51: $103-154$.

Booth, A. L., \& Frank, J. (1999). Earnings, Productivity and Performance-Related Pay. Journal of Labour Economics, 17 (3): 447-463. http://dx.doi.org/10.1086/209927

Brudney, J. L., \& Condrey, S. E. (1993). Pay for Performance: Explaining the Differences in Managerial Motivation. Public Productivity and Management Review, 17 (2): 129 - 44. http://dx.doi.org/10.2307/3380509

Caiden, G.E., \& Caiden N.J. (1997). Administrative corruption. Public Administrative Review, 37, 301-309. http://dx.doi.org/10.2307/974828

Campbell, D. J., \& Campbell, K.M (1998). Merit Pay, Performance Appraisal and Individual Motivation. 


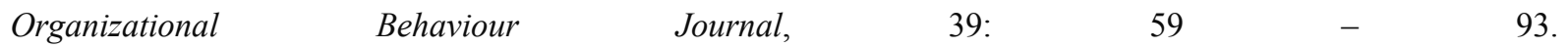
http://dx.doi.org/10.1002/(SICI)1099-050X(199822)37:2<131::AID-HRM4> 3.0.CO;2-X

Chia, H.B. (1998). An Analysis and Alternative of Human Resource Management. Academy of Management Journal, 37 (2):131-146.

Condrey, S. E., \& Brudney, J. L. (1992). Performance-Based Managerial Pay in the Federal Government: Does Agency Matter? Journal of Public Administration Research and Theory, 2 (2): 157 - 74.

Daley, D. (1987). Merit Pay Enters with a Whimper: The Initial Federal Civil Service Reform Experience. Review of Public Personnel Administration, 7 (2): 72 - 79. http://dx.doi.org/10.1177/0734371X8700700206

Deci, P. (2000). Performance Pay: An Evolving System at Spectrum Centre. Performance Management Magazine, $22-37$.

Deming, W.E. (1996). Out of Crisis. Journal of Managerial Psychology, 49: 108 - 144.

Deutsch, M. (1985). Distributive Justice: a Social, Psychological Perspective. New Haven: Yale University Press.

Dowling, B., \& Richardson, R. (1997). Evaluating Performance-Related Pay for Managers in the National Health Service. International Journal of Human Resource Management, 8 (3): 348 - 66.

Dun-lcavy, P., \& Hood, C. (1994). From Old Public Administration to New Public Management. Public Management and Money, 14 (3): 9 - 16.

Egger-Peitler, I., Hammerschmid, G., \& Meyer, R. (2007). Motivation, Identification, and Incentive Preferences as Issues for Theory to Practice 49 Modernization and HR Strategies in Local Government - First Evidence from Austria. Paper presented at the Annual Conference of the European Group of Public Administration, Madrid, Spain, September, $19-22$.

Farrell, C., \& Morris, J. (2004). Resigned compliance: Teacher Attitudes Towards Performance-Related Pay in Schools. Educational Management Administration and Leadership, $32 \quad$ (1): 81-104. http://dx.doi.org/10.1177/1741143204039301

Fletcher, C., \& Williams, R. (1996). Performance Management, Job Satisfaction and Organizational $\begin{array}{lllllll}\text { Commitment. British Journal of } & \text { Management, } & 7 & \text { (2): } & 169 & - & 79 .\end{array}$ http://dx.doi.org/10.1111/j.1467-8551.1996.tb00112.x

Fosh, P. (1998). Attitudes of East African White-collar Workers to Income Inequalities. International Labour Journal Review, 117 (1): 99 -109.

Gabris, G. T., \& Ihrke, D. M. (2000). Improving Employee Acceptance toward Performance Appraisal and Merit Pay Systems: The Role of Leadership Credibility. Review of Public Personnel Administration, 20 (1): 41 - 53. http://dx.doi.org/10.1177/0734371X0002000104

Gomez-Mejia, L. R. (1992). Structure and Process of Diversification, Compensation Strategy, and Firm Performance. Strategic Management Journal, 13 (5): 381-397. http://dx.doi.org/10.1002/smj.4250130506

Gomez-Mejia, L., \& Balkan, D. (1992). Compensation: Organizational Strategy and Firm Performance. Cincinnati: South Western Publishing Company.

Hatry, H. P., Greiner, J. M., \& Gollub, R. J. (1981). An Assessment of Local Government Management Motivational Programs: Performance Targeting with and without Monetary Incentives. Washington, DC: Urban Institute Press.

Heinrich, C. J. (2007). False or Fitting Recognition? The Use of High Performance Bonuses in Motivating Organizational Achievements. Journal of Policy Analysis and Management, 26 (2): $281 \quad-\quad 304$. http://dx.doi.org/10.1002/pam.20244

Henderson, R. (1998). Compensation Management: Rewarding Performance. New Jersey: Prentice-Hall.

Heneman, H. G., \& Young, I. P. (1991). Assessment of Merit Pay Program for School District Administrators. Public Personnel Management, 20 (1): 35 - 47.

Ingraham, P. W. (1993). Of Pigs in Pokes and Policy Diffusion: Another Look at Pay-for-Performance. Public Administration Review 53 (4): 348 - 56. http://dx.doi.org/10.2307/977147.

Jones, G.R., \& George, J.M. (2007). Contemporary Management. (5 $5^{\text {th }}$ Edition). Boston: McGraw-Hill/Irwin.

Kellough, J. E., \& Lu, H. (1993). The Paradox of Merit Pay in the Public Sector: Persistence of a Problematic Procedure. Review of Public Personnel Administration, $13 \quad$ (2): $45 \quad-\quad 64$. http://dx.doi.org/10.1177/0734371X9301300204 
Kellough, J. E., \& Selden, S. C. (1997). Pay-for-Performance Systems in State Government: Perceptions of State Agency Personnel Managers. Review of Public Personnel Administration, 17 (1): 5 - 21. http://dx.doi.org/10.1177/0734371X9701700102

Kessler, I., \& Purcell, J. (1992). Performance-related Pay: Objectives and Application. Human Resource Management Journal, 2 (3): 16 - 33. http://dx.doi.org/10.1111/j.1748-8583.1992.tb00258.x

Lawler A., \& Henderson B. (1998). Wages and Salaries. London: Irwin.

Lawler, A. (1981). Wages and Salaries. London: Irwin.

Lupton, T., \& Bowey, A.M. (1996). Wages and Salaries. Toronto: Irwin.

Marguerison, C. (1997). A Constructive Approach to Appraisal. Journal of Management Studies, 18: 30-34.

Marsden, D. (2004). Role of performance-Related Pay in Renegotiating the 'Effort Bargain': The Case of the British Public Service. Industrial and Labour Relations Review, 57 (3): 1-23. http://dx.doi.org/10.2307/4126656

Marsden, D., \& Richardson, R. (1994). Performing for Pay? The Effects of "Merit Pay" on Motivation in a Public Service. British Journal of Industrial Relations, $32 \quad$ (2): $243-61$. http://dx.doi.org/10.1111/j.1467-8543.1994.tb01043.x

Maslow A. (1954). Motivation and Personality. New York: Harper and Row Publishing.

Mattis, J. (2006). Human Resource Management. Ohio: South Western Company.

McCloy, R. A., \& Wise, L. L. (2002). Invited Reaction: The Effects of Personality, Affectivity, and Work Commitment on Motivation to Improve Work through Learning. Human Resource Development Quarterly, 13 (4): 377-382. http://dx.doi.org/10.1002/hrdq.1039

Milkovich, G. T., \& Wigdor, A. K. (1991). Pay for Performance: Evaluating Performance Appraisal and Merit Pay. Washington, DC: National Academy Press.

Milkovich, G.T. (1998). Does Performance-based Pay Really Work in Compensation Management? Journal of Human Resources, 111 - 118.

Milkovich, G.T., \& Newman, K. (1996). Compensation. ( ${ }^{\text {th }}$ Edition). Montreal: Irwin.

Mullins, L. (2004). Organizational Behaviour. (6th Edition). Boston: Irwin.

Nestle Ghana Limited. (2005). Nestle Newsletter, 12: 5 - 29.

Neuman, W.L. (2007). Basics of Social Research: Qualitative and Quantitative Approaches. (2 ${ }^{\text {nd }}$ ed.). Boston: Pearson Education.

Opsah, R.L., \& Dunette, S. (1998). The Role of Financial Compensation in Industrial Motivation. Journal of Organizational Behaviour, 34: 18 - 29.

Pearce, J. L., \& Perry, J. L. (1983). Federal Merit Pay: A Longitudinal Analysis. Public Administration Review, 43 (4): 315 - 25. http://dx.doi.org/10.2307/975834

Pearce, J. L., Stevenson, W. B., \& Perry, J. L. (1985). Managerial Compensation Based on Organizational Performance: A Time Series Analysis of the Eff ects of Merit Pay. Academy of Management Journal, 28 (2): 261 - 78. http://dx.doi.org/10.2307/256200

Perry, J. L. (1986). Merit Pay in the Public Sector: The Case for a Failure of Theory. Review of Public Personnel Administration, 7 (1): 57 - 69. http://dx.doi.org/10.1177/0734371X8600700105

Perry, J. L., Engbers, T. A., \& Jun, S. Y. (2009). Back to the Future? Performance-Related Pay, Empirical Research, and the perils of Resistance. Public Administration Review, 69 (1): 33-51.

Perry, J. L., Mesch, D., \& Paarlberg, L. (2006). Motivating Employees in a New Governance Era: The Performance Paradigm Revisited. Public Administration Review, 66 (4): 505 - 14. [Online] Available: http://www.aspanet.org/scriptcontent/custom/staticcontent/t2pdownloads/PerryArticle.htm (September 22, 2008) Porter, L.W., \& Lawler, E.E. (1968). Management Attitudes and Performance. Madrid: Irwin.

Price, R.M. (1995). Society and Bureaucracy in Contemporary Ghana. California: University of California Press.

Risher, H., \& Fay, C. H. (2007). Managing for Better Performance: Enhancing Federal Performance Management Practice. Washington, DC: IBM Centre for the Business of Government.

Robins, S.P., \& Stuart-Kotze, R. (1998). Management. (2nd Edition). Toronto: Prentice-Hall.

Rynes, S. L., Gerthart, B., \& Minette, K. A. (2004). The Importance of Pay in Motivation: Discrepancies 
between What People Say and What they Do. Human Resource Management, 43 (4): $381-394$. http://dx.doi.org/10.1002/hrm.20031

Schuler, R.S. (1998). Personnel and Human Resources Management. (3rd Edition). Toronto: West Publishing Company.

Schwab, D. (1996). Conflicting Impacts of Pay on Employee Motivation and Satisfaction. Human Resource Management Journal, 53: 190-206.

Sullivan, J.F (1992). Indirect Compensation: The Years Ahead. California Management Review, 2: $198-205$. http://dx.doi.org/10.1109/EMR.1982.4305881

Swabe, A.I.R. (1989). Performance-related Pay: A Case Study. Employee Relations, 11 (2): 17-23. http://dx.doi.org/10.1108/EUM0000000001016

Swanson, R. A. (2007). Analysis of Improving Performance: A Tool for Diagnosing Organizations and Documenting Workplace Expertise. San Francisco: Berrett-Koehler Publishers.

Synderman, S. (1999). The Merit and Demerit of Merit Pay. Human Resource Management Review, 112: 31 - 40.

Van Eerde, W., \& Thierry H. (1996). Vroom's Expectancy Models and Work-Related Criteria: A MetaAnalysis. Journal of Applied Psychology, 81 (5): 575 - 89. http://dx.doi.org/10.1037/0021-9010.81.5.575

Wallace, M., \& Fay, C. (1998). Compensation: Theory and Practice. Boston: Kent Publishing Company.

Table 1. General Population and Sample of Employees and Managers

\begin{tabular}{|l|c|c|}
\hline Respondents (Departments) & Population & Sample \\
\hline Human resource & 5 & 3 \\
Marketing & 10 & 5 \\
Production & 55 & 40 \\
Public affairs & 5 & 3 \\
Quality Assurance & 15 & 10 \\
General services & 50 & 20 \\
\hline Total & 140 & 80 \\
\hline
\end{tabular}

Table 2. Awareness of Standard of Performance

\begin{tabular}{|l|c|c|c|c|}
\hline Responses & Number & Percent & \multicolumn{1}{|l|}{ Mean } & Standard Deviation \\
\hline Yes & 70 & 87.5 & 43.6 & 2.5 \\
No & 8 & 10.0 & 34.1 & 1.9 \\
Not Sure & 2 & 2.5 & 55.3 & 4.1 \\
\hline Total & 80 & 100.0 & 44.3 & 2.8 \\
\hline
\end{tabular}

Table 3. ROCE for the Years 1994 - 2004

\begin{tabular}{|c|c|}
\hline Year & ROCE \% \\
\hline 1994 & 11.8 \\
1995 & 9.1 \\
1996 & 9.0 \\
1997 & 9.4 \\
1998 & 8.0 \\
1999 & 4.1 \\
2000 & 6.4 \\
2001 & 6.4 \\
2002 & 7.0 \\
2003 & 7.0 \\
2004 & 6.8 \\
\hline
\end{tabular}


Table 4. PBP Motivates or De-motivates

\begin{tabular}{|l|c|c|c|c|}
\hline Responses & Number & Percent & Mean & Standard Deviation \\
\hline Motivated & 45 & 56.3 & 33.4 & 3.3 \\
De-motivated & 20 & 25.0 & 19.2 & 1.4 \\
Not Sure & 15 & 18.7 & 16.4 & 5.2 \\
\hline Total & 80 & 100.0 & 23.0 & 3.3 \\
\hline
\end{tabular}

Table 5. Pearson's Correlation Test Result on Nature of Relationship between PBP and Organisational Performance

\begin{tabular}{|c|c|c|c|c|c|}
\hline Variable & $\mathrm{N}$ & $\begin{array}{l}\text { Pearson } \\
\text { correlation }\end{array}$ & Sig (1-tailed) & Mean & $\begin{array}{l}\text { Standard } \\
\text { Deviation }\end{array}$ \\
\hline $\begin{array}{c}\text { Relationship between PBP and } \\
\text { organisational performance }\end{array}$ & 80 & -0132 & 0.427 & 35.7 & 2.2 \\
\hline
\end{tabular}

Table 6. INDEPENDENT T-test RESULTS ON Corporate Performance before and after PBP

\begin{tabular}{|l|l|l|l|l|}
\hline Employees & N & Mean & Sig of dif & Df. \\
\cline { 1 - 4 } PBP & 46.5 & 37.413 & $\begin{array}{l}\mathrm{p}=0.008 \\
\mathrm{p}=\mathrm{s}\{2 \text { tailed }\}\end{array}$ & \multirow{2}{*}{148} \\
\cline { 1 - 4 } After & 33.6 & 32.753 & & \\
\hline
\end{tabular}

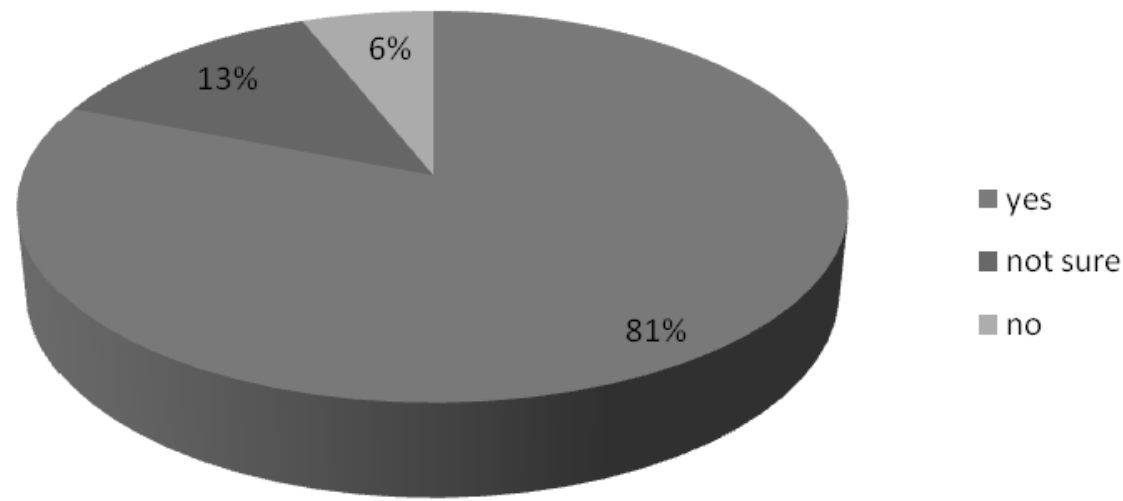

Figure 1. Motivation by PBP

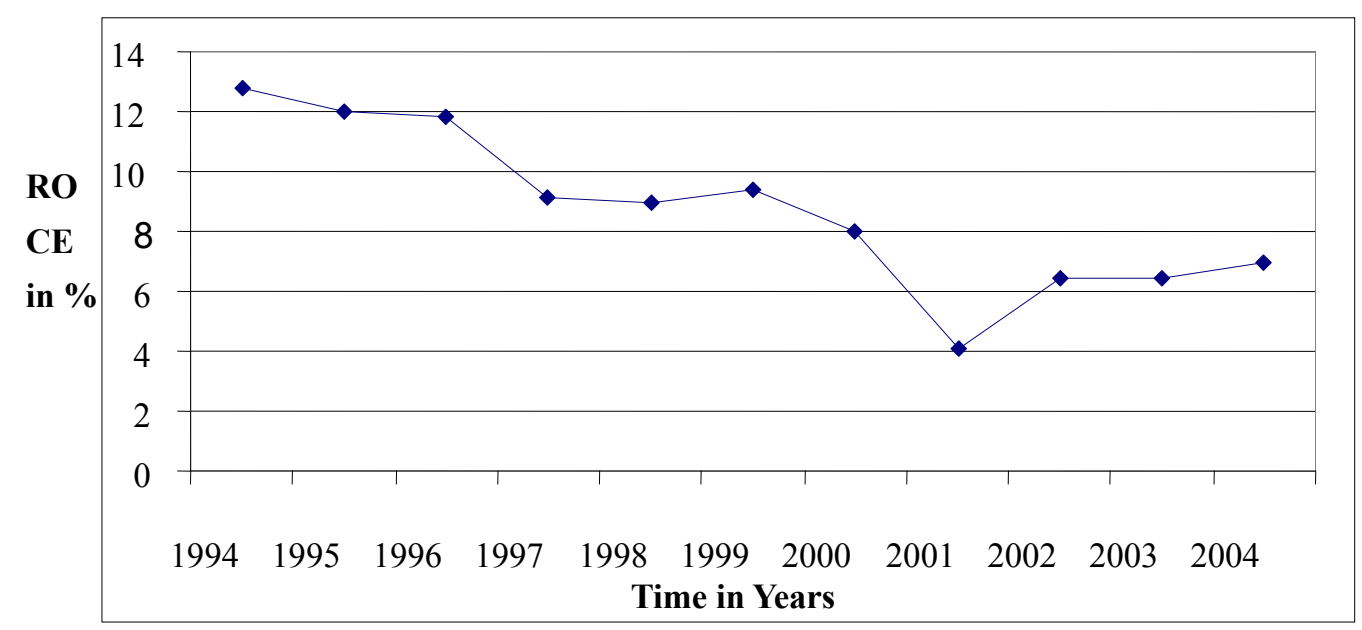

Figure 2. Assessment of Corporate Performance before and after PBP 


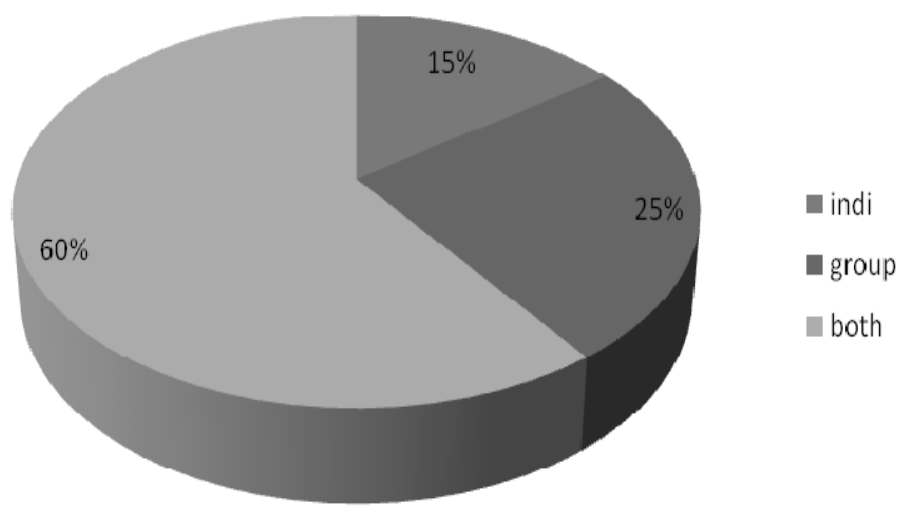

Figure 3. Preference for PBP Scheme

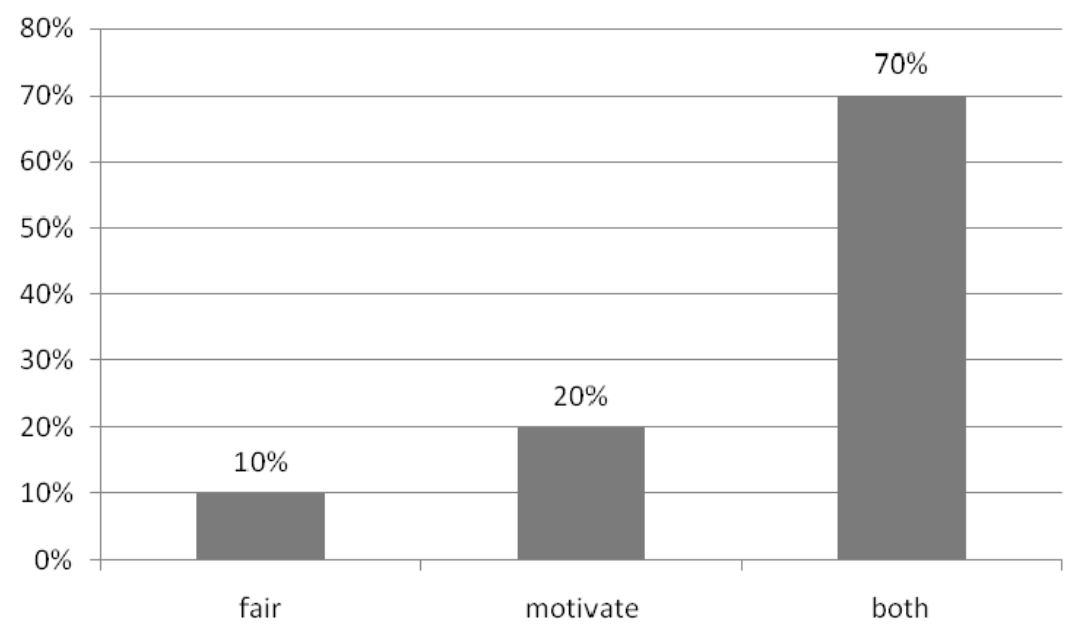

Figure 4. Importance of Performance Assessment 